\title{
Human Resource Management: The Consequences of Changes in Government Management
}

\author{
Ghofran Ahmed \\ Department Bachelor in Management, Faculty of Economics and Business Administration, \\ Lebanese University, Lebanon
}

\begin{abstract}
Employees as human resources (HR) are a central factor in an organization. Managing people in management is closely related to organizing management itself. Increasing benefits in the aspect of workability within the organization is a major consideration for HRD policies. The HRD policy is closely related to the HRM aspect, namely investing in people and developing the organization's human capital. To get employees who are efficient in the organization, then placing the humanitarian aspect as the basis for employee development. Through reforms at the organizational level both for individual employees in particular and the organization in general, a human power based perspective is offered. There is a new trend of organizations that are more consumer-oriented, and involve them in strategic planning processes that do not interest most of them. This can apply to public sector organizations.
\end{abstract}

Keywords: Human Resources, Government Management, Employees

Received: August 12, 2020

Received in Revised: August 24, 2020

Accepted: August 27, 2020

\section{Introduction}

Today, many public and private organizations are trying to maintain the existence or existence of a company or organization. Many efforts from public and private organizations emphasize their employees or employees to be nurtured more deeply, which is intended to have an impact on performance and provide outputs and outcomes for the organization.

Organizational efforts in coaching and enhancing employees in human resource management vary greatly between public and private organizations (Ellinger \& Beattie, 2009). The diversity of these efforts is reflected in the values that the organization tries to instill in its employees, so that the expectations of increasing human resources can meet the desired standards.

Managing people in management is closely related to organizing management itself. The causal relationship between management variables is that it can be determined and stated in general, it still needs to be researched through more advanced research and modification (Lewin \& Minton, 1986; Deci et al., 1989). So, the main key in building an organization is to treat people holistically. Companies need to realize that every individual has two main needs. First, to meet the needs of a decent life with adequate clothing, food, shelter. Second, is the need for people to be able to contribute to fulfilling the satisfaction of their self-esteem. Brumback (2003) explains that technological changes, human life views, and environmental complexity have influenced organizational behavior and led to more fundamental changes in the way organizations are managed. A new concept of humanity that is based on broad knowledge of human needs is complex and changing. The philosophical transition to this new concept is based on organizational values which refer to democratic-humane ideas by replacing the idea of a bureaucratic value system that is mechanical and undermines human values. In addition, there has also been a shift in the concept of power in organizations from a model based on coercion and threat to a model based on collaboration and common sense. 
As long as the mindset doesn't lead to complete human development, then whatever systems and methodologies we use will not be effective. Therefore what must be done to fulfill human needs as a whole includes the understanding that each individual has a family, social life, and religion. Because of that, nowadays advanced organizations are starting to hold family days, children days, celebrating or congratulating employees on birthdays, providing health insurance, religious facilities, and sports. This means that the organization realizes the need to touch all aspects of its employees' lives as whole human beings. To some extent, some organizations allow their employees to leave to carry out various social activities, to participate as members of certain organizations.

\section{Humans as Individuals in Organizations}

The tendency of each individual to give the best contribution is largely determined by the suitability of his vision with the organization's vision (Damanpour \& Schneider, 2006). When the management of an organization does not have time to communicate with its subordinates, it can also mean that the organization does not treat its employees as holistic humans. It could be that employees are only seen as numbers or machines. In good organizations there is always a forum to meet employees at every level. There are dialogue forums ranging from small groups to joint meetings on a larger scale. Imagine if an employee in a public or private organization worked eight hours a day as a machine mechanic operator and for years was only in charge of supervising the automatic output of the machine and the employee was rarely consulted by the chief executive. This attitude is the same as treating employees mechanically like robots.

To get employees who are efficient in the organization, then placing the humanitarian aspect as the basis for employee development. Through reforms at the organizational level both for individual employees in particular and the organization in general, a human power based perspective is offered.

\section{Human Resource Development (Employee)}

Employee development in some literatures has the same meaning as training. However, some other literature clearly distinguishes between the two, although sometimes the meaning between development and training becomes vague and unclear.

Employee development as an effort to improve quality, such as: skills, knowledge, expertise and character of employees is carried out through education and training. The education and training provided to employees must be in accordance with the required requirements, so that employee quality improvement will be fulfilled.

Meanwhile, the notion of employee development in organizations according to Armstrong is more inclusive, that strategic human resource development is about the development of a learning organization and the need for learning opportunities, development and training in order to improve individual, team and organizational performance (Lie et al., 2007).

Strategic human resource development includes introducing, eliminating, modifying, directing and guiding processes and responsibilities in a way in which all individuals and teams are equipped with the skills, knowledge and competencies they need to carry out the current and future tasks required by them. organization (Armstrong, 2003).

Human resource development has a broad and long-term view in its strategy to support the achievement of organizational goals. Human resource development strategies are developed from private organizations, which have a positive role in helping to ensure the achievement of their goals. To do this, it is important to develop the foundation of skills and intellectual 
capital that the organization needs, such as ensuring that the right quality of people is available to meet present and future needs.

Human resource development is developed in private organizations by taking into account individual aspirations and needs. Increasing benefits in the aspect of workability within the organization is a major consideration for human resource development policies. PSDM policy is closely related to the human resource management aspect, namely investing in people and developing the organization's human capital (Baron \& Armstrong, 2007).

The understanding of employee development and training explains that training is directed to help employees better fulfill their current employment, while development represents a future-oriented investment in employees (Lister, 2003).

Increasing the ability to carry out tasks now, while development emphasizes increasing the ability to carry out new tasks in the future, but because the relationship between the two is very close, the distinction difference is not something that needs to be highlighted even though it needs attention. Stated in another way, training is a form of short-term investment, while development is an investment in human resources for the long term (Tsui \& Wu, 2005).

From the various explanations above, it can be concluded that employee development is a learning process that is manifested in the form of training, both direct and indirect training for employees. The training education provided will not only provide progress on employee motor skills, but more than that it will have an impact on employees' emotional performance in the organization. Due to differences in the human character of each individual employee, the output produced by each employee from development efforts varies greatly depending on the intelligence and experience of the individual (Lepak \& Snell, 2002).

Basically, the brain gets filtered information first through receptors or taste (sense). Input (information) is filtered through a selection process, in which the brain decides whether to accept the information or not. The information is filtered so that only the selected part is received by the brain. The information is filtered so that only the selected part is received by the brain, then shaped and adjusted to the views and attitudes of the recipient of the information. Furthermore, the individual determines the form of the response, tests it and delivers. The actions and reactions that occur then are stored in the memory for future use. The more information received and tested, the memory stores in the brain become more full and richer. However, the larger the database stored in the brain, the longer it takes to search for it. As the information stored becomes more complex, the possibility of distortion becomes higher.

\section{The consequences of changes in local government management}

The emergence of local government authorities has brought about a number of changes in the management of local government resulting in new policies. One of the existing local government professions, is urban and state planning which sees its role greatly expanded to include the development of government and local authorities with the introduction of City and State Structure and Planning in 1968 and 1971. Designers and other local authority officials have acquired skills in communication, negotiation, and coordination which they describe as the relationships associated with individuals and departments eg, planning departments.

The ideal local authority, for proponents of a solution-based market, is one that meets within a year to review and allow tenders for service provision. then a successful tender to provide the services for which local authorities are responsible. However, in practice local governments continue to be the major service providers and must in any case monitor contractors to ensure that the services they provide are satisfactory. The problems inherent in 
competitive tenders became clear when the Wandsworlh Borough Council, which had tendered housing maintenance for ILS people for private contractors, found that the portions of meals served in the private houses run by these people had been reduced to deep hunger levels. in order to protect the company's profit margins. The contractor in question is exhausted. There are other cases, both in local government and in the National Health Service, where a contractor has to be suspended for failing to meet contractual requirements.

One market-based development solution that has in common is increasing concern with clients as consumers rather than as members of a wider community.

Therefore, consumer concern may require an enabling policy for service departments and service providers, which in turn results in weak management at the center of the organization (Isaac-Henry \& Painter, 1991). We need to remember that in implementing consumer reforms for local authority services, we are dealing not only with consumers in a commercial sense but with citizens. Citizens have the rights they expect to be able to enforce their aspirations, if they do not like the way local authorities are exercised, and also the election of controlling councilors out of office. Citizen rights are being augmented and published through the publication of The Citizen Charter and associated Charters covering certain public services. Reforms intended to make the needs of local authorities more accessible and responsive to consumers vary from cosmetics to extensive consumer research (Fenwick et al., 1989).

One other consequence of the development of governance of local authorities was the highly variable structural influence they exercised before 1970. Committee and departmental structures, board leaders, and chief executives and central planning units, differed widely from one authority to another.

The public service orientation encourages three main types of change management for the future. The first is that board members should give 'direction' to their staff of authority, a proposal that seems destined for founding board members 'conviction that the energetic pursuit of their voters' case will win them an extra vote in the next election. However, this proposal is now wrapped in terms of board members building a new culture of more consumer-oriented organizations, as well as engaging them in strategic planning processes that do not interest most of them. Board members may therefore have an important role to play in changing the authority's culture.

Here, local authorities need to develop a series of partnership relationships not only with private providers of care, and voluntary agencies, but also with district health authorities, health trusts and general practitioners. The local authority's social services department with a commission that determines the needs to be met from arrangements is in place of the 'bid' licensing system from potential voluntary or private sector service providers. The contract will define not only quantity and cost but also quality. The social service department will need to. Spending a lot of time developing relationships. However, the same department is required to check by inspection that the standard of service they provide is satisfactory.

Concern with consumers may require enabling discretion for service departments and service providers, which in turn results in weak management at the center of the organization (IsaacHenry \& Painter, 1991). We need to remember that in implementing consumer reforms for local authority services, we are dealing not only with consumers in a commercial sense but with citizens. Citizens have the rights they expect to be able to uphold their aspirations, if they do not like the way local authority is exercised, and also the election of controlling council members. We can see that the rights of citizens are being added and published through the publication of The Citizen Charter covering certain public services. 


\section{Conclusion}

Preparation of human resources is a part of the consequence of the development of government management of local authorities as it forces the influence of very varied structures. There is a new trend of organizations that are more consumer-oriented, and involve them in strategic planning processes that do not interest most of them. Board members may therefore have an important role to play in changing the authority's culture. One market-based development solution that has in common is increasing concern with clients as consumers rather than as members of a wider community.

\section{References}

Brumback, G. B. (2003). The end of management and the rise of organizational democracy. Personnel Psychology, 56(2), 542.

Damanpour, F., \& Schneider, M. (2006). Phases of the adoption of innovation in organizations: effects of environment, organization and top managers 1. British journal of Management, 17(3), 215-236.

Ellinger, A. D., \& Beattie, R. S. (2009). Toward a profession of coaching? A definitional examination of 'coaching,' 'organization development,'and 'human resource development'. International Journal of Evidence Based Coaching and Mentoring, 7(1).

Lewin, A. Y., \& Minton, J. W. (1986). Determining organizational effectiveness: Another look, and an agenda for research. Management science, 32(5), 514-538.

Baron, A., \& Armstrong, M. (2007). Human capital management: achieving added value through people. Kogan Page Publishers.

Lister, R. (2003). Investing in the Citizen-workers of the Future: Transformations in Citizenship and the State under New Labour. Social policy \& administration, 37(5), 427-443.

Deci, E. L., Connell, J. P., \& Ryan, R. M. (1989). Self-determination in a work organization. Journal of applied psychology, 74(4), 580.

Isaac-Henry, K., \& Painter, C. (1991). The management challenge in local governmentemerging themes and trends. Local Government Studies, 17(3), 69-90.

Lepak, D. P., \& Snell, S. A. (2002). Examining the human resource architecture: The relationships among human capital, employment, and human resource configurations. Journal of management, 28(4), 517-543.

Tsui, A. S., \& Wu, J. B. (2005). The new employment relationship versus the mutual investment approach: Implications for human resource management. Human Resource Management: Published in Cooperation with the School of Business Administration, The University of Michigan and in alliance with the Society of Human Resources Management, 44(2), 115-121.

Lien, B. Y. H., Hung, R. Y., \& McLean, G. N. (2007). Organizational learning as an organization development intervention in six high-technology firms in Taiwan: An exploratory case study. Human resource development quarterly, 18(2), 211-228.

Armstrong, M. (2003). Handbook of Strategic Human Resource Management: A Guide to Action. Crest. 
Fenwick, J., Harrop, K., Elcock, H., \& Elcock, H. (1989). The Public Domain in an English Region: Aspects of adaptation and change in public authorities (No. 175). Centre for the Study of Public Policy, University of Strathclyde. 